\title{
Hegemony and asymmetry: multiple-chessboard games on transboundary rivers
}

\author{
Jeroen Warner • Neda Zawahri
}

Accepted: 9 March 2012/Published online: 6 June 2012

(C) The Author(s) 2012. This article is published with open access at Springerlink.com

Keywords Transboundary rivers · Hegemony · Asymmetry · Two-level games · Hydropolitics

\section{Introduction}

Water connects, and transboundary rivers connect a host of actors in different states in multiple ways. Riparian states can depend on each other for sea access, generating joint benefits and minimising the losses from natural hazards. Yet, riparians can also use the river to annoy, threaten, and damage each other by discharging wastewater into the basin or constructing sufficient dams to store and regulate the river's flow (Zawahri 2008). In an increasingly interdependent world, we would expect a growing number of transboundary river treaties as states attempt to minimise the social, economic, and political losses incurred from developing the basin and preventing unwelcome unilateral action. Such attempts at cooperation may also lead to more integrated river basin management.

Yet even when international water agreements are signed, it does not mean contracting states are actually cooperating, and the lack of agreement does not mean riparian states are fighting. In other words, the presence of a treaty does not automatically translate into behavioural altering cooperation. In the Iberian Peninsula and on the Mekong basin, for example, relations remain conflictive despite some form of institutionalised cooperation. Thus, conflict and cooperation are ambiguous terms that tend to be used to describe how states interact over their shared water resources. The objective of this special issue is to tease out the dynamics of basin conflict and cooperation where power relations are asymmetric. ${ }^{1}$ That is, we seek to examine whether power asymmetry is needed to get

\footnotetext{
1 In asymmetric basins, usually one of the riparian states is a hegemon, that is, "first among formal equals'-equal de jure but preponderant de facto.
}

J. Warner ( $\square)$

Disaster Studies, Wageningen University, Hollandseweg 1, 6706 KN Wageningen, The Netherlands e-mail: Jeroen.warner@wur.nl 
anything done, as realist hegemonic stability theory claims, or is it a hindrance for a fair deal and lasting peace among riparian states?

In an attempt to answer this question, much of the existing literature on conflict and cooperation over transboundary basins has been focused on interstate relations. We seek to qualify this research by highlighting the multi-level nature of water politics. Domestic politics has a strong bearing on international outcomes - and sometimes vice versa. In the process, we pay special attention to the way powerplay at one level constraints or enables cooperation and conflict strategies at another. As the articles in this special issue show, both the overlay of global and regional hegemonic politics and the 'underlay' of struggles between the state, sub-national authorities, and community-based organisations impinge on, or are impacted by, interstate negotiations.

Together, the articles in this special issue demonstrate that riparian states are enmeshed in at least two negotiation arenas. While domestic politics and international relations tend to be formally separated in the current literature on managing international rivers, in practice they increasingly influence each other. If political interactions are considered as games, as the articles in this special issue argue, we can observe that even powerful riparian states, such as Turkey along the Euphrates and Tigris basin, China along the Mekong basin, or India along the Ganges basin, cannot content themselves with playing at one chessboard while ignoring the other.

Conceptually, we draw on Putnam's (1988) pioneering discussion of 'two-level games' and contemporary updates such as three-level games and two-level transboundary network games. Power relations on each of these boards are rarely equal and symmetrical. Internationally, a new round in the games does not mean anything can happen-hegemonic actors may have built structural advantages that non-hegemons may willingly or grudgingly accept. Yet, faced with tough domestic opponents, the state is not necessarily the strongest and most skilful player at the board. Non-state actors, such as non-governmental organisations (NGOs), epistemic communities, and policy entrepreneurs, can enter the game and influence the outcome even under conditions of power asymmetry among the riparian states. Thus, this special section seeks to advance our understanding of the interaction between domestic and international politics along with the role of non-state actors by considering several bordercrossing international rivers that are seen as sites of conflict or weak cooperation, such as the Euphrates and Tigris, Ganges, Mekong, and Iberian basins.

In seeking to understand the presence or absence of cooperation over international rivers, the following section briefly investigates the relationship between water and national security: it examines why states might be tempted to cooperate, and considers why they may refuse to play (multi-level) river cooperation games. After an examination of the function of hegemony within the basin, we introduce Putnam's two-level games and some proposals for modification in the literature. We close with a consideration of the implications from our special issue to the management of international rivers and identify questions that remain for future research.

\section{Cooperation, coordination, and anarchy}

Freshwater is an essential resource for our survival. As populations have grown and nations industrialised, the demand on our planet's limited supply of freshwater has increased at an unsustainable rate. Drawing on a neo-Malthusian perspective that saw a direct link between population growth, natural resource scarcities, and violent conflict, some have predicted violent environmental conflicts, or water wars, in conflict-torn regions such as the Middle 
East and Africa (e.g. Starr and Stoll 1988; Ohlsson 1995). While plenty of data were mobilised to dispel the water war myth (Wolf 1995, 1998), the relationship between freshwater scarcities and conflict has regained momentum in light of climate-induced global change (Trondalen 2009).

In the wake of the findings of Wolf (1998) and others on the absence of water wars, a perhaps overoptimistic mood has taken hold of the water community, seeing cooperation as the inevitable march of history (e.g. Ohlsson and Turton 1999). More recent work such as Mirumachi and Allan's (2007) TWINS (Transboundary Waters Interaction Nexus) model and Zeitoun and Warner's (2006) work on hydro-hegemony, ${ }^{2}$ among others, served as cautionary tales against this optimism, without reverting to water wars scenarios.

While the extant literature on facilitating cooperation over international rivers tends to focus on the systemic level of analysis, studies emphasising the role of domestic actors remain rare. Consequently, the literature is weak in its consideration of how domestic constituencies, sub-national institutions, and national or international non-state actors can move states towards cooperation. This failure occurs because of the underlying assumption that has permeated the literature. That is the belief that riparian states behave as unitary actors that are relatively unconstrained by domestic politics. As Milner (1997: 11) has noted, however, states are composed of actors with 'varying preferences who share power over decision-making'. This is bound to compel states to constantly negotiate on internal and external chessboards as they attempt to develop their international basins.

The extant literature tends to argue that states' interest in negotiations and even the potential outcome of negotiations over international rivers can be influenced by states' location along the river and the distribution of military capabilities within the basin (Lowi 1993; Tir and Ackerman 2009; Zawahri and Mitchell 2011). Lowi (1993) argues that upstream states, due to geographical advantage, do not necessarily need to bother with downstream demands; they can do as they please (especially if they are the powerful riparian and have the technological capabilities). For example, there is no formal multilateral treaty between upstream Turkey and downstream Syria and Iraq in the case of the Euphrates and Tigris rivers, so that Turkey does not necessarily need to consult with its neighbours as it builds dams on these rivers (Zawahri 2006). While upstream riparians may use water to gain political control, downstream riparians tend to use military power to gain more control of the water (Warner 2004). An example is downstream Egypt along the Nile basin (Lowi 1993).

When there is a relative balance of power within the basin, riparian states can decide whether to work together voluntary or opt out (Zawahri and Mitchell 2011). States may be interested in opting out and unilaterally developing the river while ignoring the interests of other riparians. When river relations are 'anarchic', each state goes it alone and opts against communicating with its neighbours beyond the bare minimum. States may select this option if they fail to see any advantage or any gain from cooperation. That is, they may deem their Best Alternative to a Negotiated Agreement ${ }^{3}$ is the point at which no deal is better than a bad deal.

Yet, without cooperation or coordination for a riparian state that elects to develop a transboundary basin, the shadow of the future is short, transaction costs are high, and each

\footnotetext{
2 '(H)ydro-hegemony usually describes hegemonic interaction over transboundary water resources in river basins shared by two or more nations; however, it can be utilised for the exertion of power and control within a state as well' (Wegerich and Warner 2010: 254).

${ }^{3}$ Provided they are to a degree interdependent, negotiators need to determine their Best Alternative to a Negotiated Agreement, or 'walk-away alternative'. If they cannot secure a particular bottom-line, walking away from the negotiation table is preferable than staying on to negotiate an unacceptable deal.
} 
move is a surprise, which more often than not tends to involve high costs (Zawahri 2008). As Williams (2003) argues, overdevelopment of a river almost inevitably creates interdependencies that over time necessitate some kind of interaction and some form of bargaining. In the case of the Euphrates and Tigris basin, there is indeed intense bargaining and some operational cooperation between the riparians (Warner 2008). Thus, as riparian states develop their resources and interdependence increases, they almost inevitably bump into each other and influence their neighbours' interests. Ultimately, some form of communication and coordination seems inevitable as states seek to minimise the losses incurred by developing and depending on the basin (Zawahri 2008).

In between conflict resolution and opting out, riparian states may also select to manage rather than resolve a conflict through treaty formation ('tactical functional cooperation'; Sosland 2007). They may decide that there is more to be won from managing and gain something-if not as much as the stronger party (Haugaard 2006). Under tactical functional conditions, cooperation may be tacit or implicit, not based on treaties or formal negotiations (Bernauer and Kuhn 2010). An example is the Picnic Table Talks held between Israel and Jordan over the Yarmouk Tributary. These riparians met secretly to manage the basin, while they lacked formal diplomatic relations (Sosland 2007; Zawahri 2010).

\subsection{Revisiting hydro-hegemony}

The river basins examined in this special issue are all confronted with an upstream hegemonic power-China on the Mekong, Turkey on the Euphrates and Tigris, India on the Ganges, ${ }^{4}$ and Spain on all but one of the Iberian river basins. Does the presence of a hegemon in the basin contribute to cooperation? Realist theory of Hegemonic Stability argues that hegemony brings the public good of stability of expectations from which both leaders and non-leaders benefit (e.g. Mearsheimer 2001). Due to these benefits, which can include cooperation, non-hegemons may seek or accept this 'guidance' with relative ease. In other words, if the subalterns reckon they stand to gain from the terms of hegemony, they may conclude it is not worth resisting the state of affairs (Haugaard 2006).

But the hegemon's public good of stability comes at a price. In asymmetric power structures, strong states have the option to select the approach consistent with their best interests, while significantly weaker states can rarely afford to opt out of cooperation or communication. Consequently, cooperation under these conditions can limit the room for manoeuvre of non-hegemonic powers. The Ganges river is an example. India has opted to manage this multilateral river through bilateral as opposed to multilateral accords, which has enabled the hegemon to secure its interests and prevent Nepal and Bangladesh from offsetting its power. Yet, this fragmented governance has come at a cost in that it prevented the riparians from developing the basin in an integrated manner recommended by scientists for the basin's efficient development (Crow and Singh 2000).

To secure its interests, the hegemon has two tools at its disposal-control and consent. The one cannot really go without the other: power based on force only is not real power (Arendt 1972). While strongly concerned with hegemony, realist theory of international relations tends to focus on control and neglect the importance of acceptance (consent) and non-hegemon followership - to qualify as a leader, you need followers (Prys 2008). Yet, a

\footnotetext{
4 Although India is midstream along the multilateral Ganges basin, it has used its power to impose bilateral accords on its weaker riparians, upstream Nepal and downstream Bangladesh. The article in this special issue considers the interaction between upstream India and downstream Bangladesh.
} 
hegemonic analysis needs to explain how predominant states not only gain or keep the upper hand, but also command the acceptance and consent of others. To accomplish this task, a hegemon can also draw on the 'soft power' of attraction and persuasion (Nye 2004) to secure the consent of weaker states, as in the case of Turkey. The Erdoğan government in Turkey, for example, has used its 'soft power' to appease rather than confront its unruly neighbours, but continues to perceive its neighbourhood as dangerous and unruly (Aydin 2003).

The effective consent of others to a hegemon's preponderance can make it worthwhile for hegemons to assume particular burdens, as they may need to shoulder disproportionate responsibility and political risk to maintain that stability- 'it's a dirty job but someone's got to do it'. Dirty, as hegemony does not mean the stronger party always wins, or even means to win: considerable sacrifice or compromise on the part of the hegemon for the sake of stability may be part of the bargain. Hegemony in practice may express itself in benign unilateralism: self-binding for the benefit of the larger constellation. While the motives may not be entirely altruistic, as stability especially serves the hegemon's interest, the hegemon may really believe it is putting itself out for the greater good.

Non-hegemons are by no means powerless. Daoudy (2009: 360) has highlighted the bargaining power of non-hegemons reducing the hegemon's degrees of freedom in exercising power. Weaker states may take on the dominance of stronger states or use obstructive tactics. On the Rhine, the downstream The Netherlands persuaded the stronger upstream states, France and Germany, to reduce chloride pollution with side payments (LeMarquand 1977; Dieperink 2011) and now enjoys the benefits of Rhine cooperation. ${ }^{5}$ Issue-linkage can be a potent strategy for the non-hegemonic power, creating instability by reducing the dominant power's range of alternatives (Daoudy 2009).

Discussing domestic flood protection within The Netherlands, Wesselink et al. (2011) show how the non-hegemonic entity (in this case, the Limburg region) may successfully cajoled the reluctant hegemonic state (The Netherlands) into extending their flood protection arrangement, and consequently national financial responsibility, into the hinterland despite its quite different geography.

Resistance by the weak may not be so openly expressed, but manifest itself in 'weapons of the weak' (Scott 1995): tacit obstruction and boycotts of outcomes desired by the hegemon. In the water domain, in which we may speak of basin or hydro-hegemons and their opponents, we may note weaker downstream states can resort to strategies showing the upstream state does not always win in an asymmetric power structure (Shapland 1995). These include blocking access to the sea, enlisting powerful friends, or building up military capacity.

Hegemony may be challenged outright. For example, Egypt's hegemony on the Nile has long impeded hydraulic development on the Nile. Facilitated by bilateral and multilateral aid institutions, the riparians entered into a multi-stakeholder bargaining process on the Nile in the 1990s, the Nile Basin Initiative, which seemed to lead to a basin-wide treaty in 2008 but then got hopelessly stuck. In 2010, Egypt has been challenged by the unilateral conclusion of a Nile treaty by upstream riparians, without Egypt (Morrow and Al-Omrani 2010).

\footnotetext{
5 Dieperink (2011) notes that deals are more likely when parties are willing to accept each other's stakes as legitimate, when joint research is conducted within an international catchment organization that has a legal mandate to serve as a formal negotiation platform. During the negotiations downstreamers could make moral appeals to upstreamers.
} 
While strong counter-hegemonic opposition can manifest itself at multiple levels, hegemons and non-hegemons more routinely appear to negotiate the terms of hegemony continuously (Watson 2007). Weaker states are more likely to engage in the coerced cooperation' to minimise the losses from interdependencies. Others in the hegemonic setup may be tempted or forced to go along with the hegemonic agenda. Manifest, institutionalised international cooperation does not preclude these power games, as stronger parties may cajole weaker states into accepting something to the hegemonic power's advantage. This is illustrated in Lopes' (this issue) study of the Iberian basin in which Spain, the hydro-hegemon, succeeded in framing a river cooperation treaty that largely secures its own interests, and getting Portugal, downstream on almost all rivers, to sign it.

However, as all three cases in this special issue show, the shape and content of hegemonic arrangements are not immutable. While Iberian hydropolitics until the ' $90 \mathrm{~s}$ fit well within a Realist framework, Portugal colluded with Spain's predominance. Yet, Lopes (this issue) argues, closer cooperation transformed the two states' relations into something closer to 'hydro-solidarity', eroding the primacy of state sovereignty. In Asia, Zawahri and Hensengerth (this issue) observe a changed hydro-hegemonic state discourse on water, incited by domestic NGOs concerned with sustainability. Finally, the Euphrates and Tigris riparians have resorted to the elevation of water to national security with a view towards widening or narrowing the power gap between the hydro-hegemon and non-hegemons (Zeitoun and Warner 2006). Warner (this issue) argues that basin hegemonic relations have been reshaped by the combination of the ascent of a different ruling party in Turkey, changing the country's foreign-policy outlook and the US defeating Iraq's leadership and overtaking its international relations-with Syria currently a question mark.

On the basis of her Iberian case study, Lopes argues that the hydro-hegemony approach is too Realist and state-centric in its outlook, too embedded in a Westphalian concept of sovereignty, and underappreciating structural positive-sum outcomes. The hydro-hegemony literature has tended to overlook the increasing blurring relationship between states and non-state actors (Lopes this issue; Suhardiman and Giordano this issue). Although compliance with hegemony does not exclude win-win outcomes (see Haugaard 2006), this gives a more liberal-institutionalist flavour to hydro-hegemonic analysis. Stepping away from state-centricity in favour of a two- or multi-level approach, moreover, foregrounds the importance of domestic and international non-governmental organisations in changing the water discourse and, potentially, action. The next section will elaborate on this point.

\section{Power asymmetries, domestic politics, and non-state actors}

The articles in this special issue advance the literature on managing international rivers into a more dynamic, multifaceted, and multi-level perspective of hydro-hegemony. Hegemons are forced to interact and defend their position in the international, regional, and domestic arenas. These multi-level interactions can make hegemony harder to maintain (Warner 2008).

A regional or basin hegemon cannot count on automatic legitimacy and needs to run a 'tight ship at home' (Warner 2010). At the domestic level, the central state cannot count on its predominance. Maintaining hegemony may require major concessions to the domestic subaltern, who may exploit the need for continued compliance at home by winning concessions. Hegemons will need to safeguard their sovereign position vis-à-vis political and social contenders domestically and region-wide. That is, hegemonic states can select to ignore domestic pressures, but at their peril. 
In looking at the influence of regime type on the behaviour of riparians, it appears that democracies behave differently when they share a basin with other democracies (Gerlak et al. 2011; Zawahri and Mitchell 2011; Tir and Ackerman 2009). Democratic dyads are more likely to sign treaties to govern their international basins, and they are more likely to invest in designing these accords (Zawahri and Mitchell 2011; Tir and Stinnett 2011). Zooming in on how transboundary cooperation tends to involve a time-consuming information and data-sharing exercise, as part of the larger institutionalisation of cooperation, Gerlak et al. (2011) discover that democracies seem to share more with their co-riparians than non-democracies, they do so ambiguously, that is, with deliberate vagueness in data exchange in order to allow for greater flexibility in the face of resource uncertainty.

While the extant literature does seem to support the general proposition that regime type influences riparian states' behaviour, the articles in this special issue demonstrate that nonstate actors can have an impact on democratic and authoritarian regimes. That is, authoritarian governments like China can seek and work to stifle NGO action and policy entrepreneurs. Democracies can also select to disregard or counter domestic discontent from interest groups and international pressure groups. But non-state actors, in either democratic or authoritarian regimes, find means by which to promote their policy preferences and alter the behaviour of the powerful hydro-hegemon. Along the Mekong River, Chinese NGOs operate within a highly confined environment, but they still managed to influence the Chinese government's willingness to protect biodiversity within the basin (Zawahri and Hensengerth this issue). Consequently, even autocracies need to heed and utilise their domestic audience (see Weiss 2010). In democratic Turkey and democratic India, NGOs have managed to alter, or at least challenge, the behaviour of relatively powerful regional hegemonic states (Warner this issue; Zawahri and Hensengerth this issue). Thus, the special issue demonstrates that regardless of regime type, governments can be persuaded to consider the demands of interest groups and NGOs.

\subsection{Putnam's two-level games}

The mutual influencing of separate 'chessboards' on which states play has been noted by Putnam (1988), who was one of the first to argue that domestic and international politics strongly influence each other: 'central decision-makers strive to reconcile domestic and international imperatives simultaneously' (...) 'moves that are rational for a player at one board...may be impolitic for that same player at the other board' (Putnam 1988: 343). While negotiating with opponents, states are simultaneously negotiating with the home team. Maximising the outcome at the international board can help satisfy domestic pressures and minimise the impact of international developments, while inconsistency between the two boards is to be expected along the way. Although Putnam explicitly applied his model to liberal democracies, arguing these can leverage the 'audience costs' of backing down, Weiss (2010) has noted authoritarian regimes also have to contend with excitable audiences, which they may use to their advantage in international relations.

The key issue in two-level games is the 'win-set', that is the set of all possible international agreements that would be acceptable at the domestic level (Putnam 1988: 437). In the water domain, the geography of transboundary basins may play an important role in defining the size of the win-set. In the border-crossing examples in this special section, the win-sets of upstream riparians are much smaller than those of downstream states, because upstreamers can leverage their control over water resources (Keck and Sikkink 1998). 


\subsection{Power strategies in the domestic-level game}

The articles in this special issue challenge the Realist state-centred understanding of the measurement of power from a purely military, economic, or geographic sense and the type of actors that exercise power. What are considered relatively weak actors from the Realist perspective, such as NGOs, policy entrepreneurs, and epistemic communities, can use their specialised knowledge, networks, and 'soft power' to challenge the authority of powerful states and alter the power equation. Moreover, as this special issue's review article by Suhardiman and Giordano (this issue) reminds us, the lines between state and non-state sectors are blurred; the same actor may belong to both sectors.

Collectively, the articles introduce the various types of power exercised by non-state actors, which includes lobbying government officials, mobilising the public in protests, leaking reports to the media, challenging existing discourse, and resorting to litigations to persuade sub-national actors to comply with environmental legislation. Non-state actors can also follow the 'boomerang' strategy by enlisting international allies to mobilise international opinion to pressure the domestic government (Keck and Sikkink 1998). How do you get your government to change its mind on an issue that touches on key values? Local social movements can enlist international allies to mobilise international opinion to pressure the domestic government (Ibid).

Consequently, science, information, or data in the hands of relatively marginalised nonstate actors become a weapon that compels militarily powerful states, such as Turkey, India, and China, to alter their behaviour. In the case of Turkey, non-state actors succeeded in delaying the construction of a dam, while in India and China, they 'encouraged' the state to comply with its own policies to clean the river (Warner this issue; Zawahri and Hensengerth this issue). While downstreamers may need scientific expertise to legitimise their claim, the usefulness of the data is in its scientific value, as in its instrumentality-its success in counteracting hegemonic power.

\subsection{Three-level games}

In addition to qualifying the power rationale of the literature on hydro-hegemony, this special section also advances the assumptions of two-level games. Putnam (1988) wrote his analysis in the relatively simple bi-polar world. But the post-Cold War world is much more complex, and, as a result, his model fails to consider the multitude of other actors involved in the negotiations. These multiple actors can move negotiations into multi-level interactions. An example of this multiple interaction is presented by Knopf (1994), who sees three types of transboundary interactions. The first type concerns transgovernmental interactions (interactions involving governmental official), the second is transnational interactions (interactions involving actors outside the executive branch), and, finally, the third is cross-level exchanges (interactions involving two different types of actors). Alliance relationships can also affect the negotiation process and results.

When states are operating in three-table negotiations, the players at two tables may exert joint pressure on the game at the remaining table. Today the European Union (EU) and other multilateral organisations, such as NATO, can also constitute a third level, that is, a third arena or table in the multi-level interaction (Balaban Balaban 2006). Does the integration achieved by the EU render lower-level chessboard games less explosive? Not necessarily so, as seen in this special issue. Even within this integrated economic union, riparian states still clash with each other over water. The Netherlands and Belgium on the river Scheldt (Warner and van Buuren 2009) and Hungary and Slovakia on the Danube 
BOX 1 Example: the river Scheldt as a multi-level game

A truly transboundary multi-stakeholder network was tried on the river Scheldt (Warner and van Buuren 2009). After centuries of mostly conflictive interaction between the Scheldt estuary riparians, dating back to the sixteenth century, the riparians The Netherlands and Belgium invited governmental, business (harbour), and NGO actors around the table to hammer out a compromise deal on the future management of the estuary. As the dynamics of the estuary are extremely complex and controversial, a considerable budget was made available to fund impartial research on the downstream effects of upstream river interventions, especially the deepening of the channel for roll-on-, roll-off transport

A trilateral multi-stakeholder process or platform (MSP) ${ }^{a}$ between public, private, and civil-society actors from both states started in 2003. After a slow start, things took an upswing when the harbour of Antwerp and environmental NGOs found agreement on a modality of river deepening with reduced environmental impact, leading to a Dutch-Belgian agreement in 2005. But farmers and local interests on both sides, frustrated with their limited role in the negotiations, successfully lobbied the Dutch government to call the agreement off. While historic grievances over Dutch dominance reduced mutual trust, Dutch domestic politics eventually meant the downfall of the agreement. The Belgian government responded angrily and threatened to retaliate on other issues of interest to the two countries. At of this writing, the Dutch were still tabling alternatives

While the negotiation process unfolded at two tables, a third layer cast its shadow - the EU, whose legal framework such as the 2000 European Water Framework Directive and similar policy guidelines stated that downstream riparians should grant upstream riparians access to the sea and that environmental damage caused by an upstream intervention should be compensated elsewhere. If the Dutch alternative now proposed fails to live up to these standards, it will have to be negotiated with European authorities as well.

MSP constellations, interpreted as transboundary policy networks, are still rare on shared rivers, and none of the case studies in this special section conform to these characteristics. This case, however briefly outlined, may illustrate that even in an integrated region, shared benefits, stakeholder processes, and social learning are hard to translate into a tangible, ratified, and implemented river plan.

${ }^{a}$ A well-accepted definition among many sees a multi-stakeholder platform or process is "a decisionmaking body (voluntary or statutory) comprising different stakeholders who perceive the same resource management problem, realize their interdependence for solving it, and come together to agree on actions for solving the problem".

(e.g. in Giordano and Wolf 2003) are examples. And as Lopes (this issue) shows, Spain and Portugal along the Iberian basin have confronted water conflicts. In each of these conflictive river management situations, water management is to a degree 'securitised' subject to national security considerations.

While two-level games, some multi-level games, and securitisation analysis are still ultimately state-centric, a different, liberal perspective has been gaining headway. Multistakeholder settings (see Box 1) bring interesting twists to the two-level games theorised by Putnam (1988). The European context has drawn attention to the importance of transboundary-including transnational-governance networks (Morin 2010). These networks are like cobwebs (Burton 1972) rather than the unitary billiard balls of the Realist world view: actors representing one of the negotiating states may not act in concert, but may strike alliances within and across borders to achieve certain goals. Such networks can

\footnotetext{
6 'Securitising' an environmental issue implies subjecting it to a military security logic-top-down decision-making, classifying information, bypassing normal standards of participation and economic valuation. Securitisation theory sees security as a social construction with a political rationality. It is to affix a security label on an issue that is of key importance to the speaker. If the audience accepts the urgency discourse, the security framing is successful. The felicity of the concept of 'security' does not only have an immediate policy audience (policy makers, electorate, funders) but also a wider regime context, a discursive community. Regional water players are embedded in a larger international constellation they can seek to influence, but cannot easily ignore. To gather support for a security strategy, their concerns have to resonate with the international discourse.
} 
be said to have four (ideal-typical) characteristics: all relevant stakeholders participate, state and non-state actors interact on a non-hierarchical basis process, and decisions are made consensually in a multi-level decision-making process rather than by a majority vote or through outside pressure. Finally, they are transnational and issue-based (Morin 2010).

A truly transboundary network makes decisions on a consensual basis rather than votes. While this consensual process may adequately describe procedure, we may problematise 'consensus' building under highly unequal power relations, which forces or coaxes an agreement on the weaker side that does not benefit them, or benefits them much less than other parties. Such a critical mind may see multi-stakeholder participation at least potentially as a way of co-opting and disciplining actors into forced alignment, as a condition to access or even capture particular resources (e.g. Currie-Alder 2007). The agenda and framing of basin-wide participatory processes tends to be pre-established (boxed in) by its initiator, who is rarely a neutral party. A politicised approach stresses the power asymmetries involved in a conflict situation, silencing dissident voices and promoting empowered alliances of selected, weaker stakeholders, picturing multi-stakeholder platforms involving all parties as an undesirable form of 'domestication', a way of exercising hegemony. True, hegemons may find ways of levelling the playing field somewhat to give more voice to weak stakeholders (Edmunds and Wollenberg 2001). If the field remains too skewed and the power equation too unequal, however, the weaker state cannot expect great benefit from entering into the participatory process.

As research by Milner and Moravscik (2009) and Keck and Sikkink (1998) reveals, we may also see networks as political arenas with internal and external games as well. In an increasingly interdependent world, actors meet each other at different 'chessboards' in horizontal, vertical, and diagonal interactions. States, but also multinational companies, international NGOs, transboundary criminals, and terrorists face domestic and international others. Domestic drivers influence international politics and regime formation (Haufler 1993), while the overlay of international power games and governance shapes domestic politics. A single move therefore affects multiple games. This is evident in the contributions in this special issue. Non-state actors were important in the Euphrates, Tigris, Ganges, and Mekong basins according to Warner (this issue) and Zawahri and Hensengerth (this issue).

A focus on networks opens up the power analysis to non-state actors operating outside the administrative boundaries of states. As Morin (2010) notes, 'both advocacy and business lobbies organise coalitions, exchange information,... frame issues, and succeed in influencing public policy'. This lobbying has brought interesting international results, most famously the Rhine treaty, an international water quality agreement part-instigated by environmental NGOs like Dutch Reinwater (Dieperink 2011). NGOs and companies can bypass the state negotiator to address domestic audiences with a view to pressuring government (the 'boomerang effect': Milner and Moravcsik 2009; Keck and Sikkink 1998). A finer point in this context is the conundrum that it is not always clear who started what - did local NGOs enlist the support of an international action NGO to join forces with, or did the international NGOs look for a target for its campaign and found local friends? Whichever the case may be, Keck and Sikkink's (1998) boomerang was successfully thrown in the Euphrates/Tigris dispute, as local and international activists joined forces against Turkey's dam, applauded by downstream riparians until basin politics took a more cooperative turn (Warner this issue). The cases discussed in the present special issue indeed support this advance on Putnam's essentially state-centred model. 


\subsection{Boundary spanning}

Above, we noted the role of NGOs in pushing the envelopes in multiple arenas, either to effect change or to stop it. They are not the only ones who display political entrepreneurship (Huitema and Meijerink 2010) to question and renegotiate existing boundaries, and create (or disrupt) linkages between different issues and 'games'. Where multiple chess games take place simultaneously due to the interlinkage of policy arenas, linkages between these games may be actively sought by 'boundary spanning' (or 'administrative coupling'), making horizontal, vertical, and diagonal linkages. ${ }^{7}$

Working across geographical, institutional, and time boundaries can push the boundaries of the politically possible and enable innovative change. When relations are not obviously hierarchical, negotiators may rely on subtle forms of network management with actors they are horizontally, vertically, or diagonally linked with to build coalitions to achieve ambitious goals. One such entrepreneur, known as a 'boundary spanner' (after Williams 2002), building a large policy network in the issue-area, deliberately enters into multiple games, knowing that a losing position at one board may be compensated by a better situation at another board. Some of the opponents encountered in one game may be the same in another game, but in different power constellations. Seeking to manipulate the speed of the game, for example, waiting until an opportunity in another arena arises/or gearing up to exhaust the other, is not beneath a boundary spanner. The snag is, of course, that opponents of the proposed change can use the very same strategies (Werners et al. 2010).

How does this work out across borders? As noted, while the number of transboundary treaties is growing steadily, often not much happens beyond technical coordination (Kistin 2006). Yet while international politics is often explained as interlinked two-level (vertical) games of chess, there are indeed examples of networked transboundary basin relations. These have the additional dimension of parallel, interlinked horizontal games (within and outside the multi-stakeholder learning platform). This set-up could both amplify cooperation but also conflict between the parties involved. Strategies such as vertical and horizontal 'forum (or: venue) shopping' (Huitema and Meijerink 2010) linking the issue to other, perhaps substantively unrelated chessboards can contribute to the connective capacity within the decision-making process but equally well lead to fragmentation and impasse.

In the EU context, one would expect regional integration to supersede sovereignty, creating leeway for transboundary networks sharing decision space and pushing the envelope. Sovereignty, however, has a way of rearing its head when stakes are (seen as) high (de Vries 2008). On the river Scheldt (see Box 1), non-state parties were invited at the turn of the century to develop-together with Dutch and Belgian public representatives-a long-term vision for the extremely complex Scheldt estuary system, which is shared by Flanders and The Netherlands, in line with a Belgian desire to reduce uncertainty (the shadow of the future). A non-binding learning platform was established to assess the environmental impact of deepening the Scheldt for navigation on Dutch natural values in an area of special natural beauty safeguarded by European Directives. While after much ado a deal was brokered in 2005 , this fell apart due to politicking, leading to a diplomatic

\footnotetext{
7 Bressers and Lulofs (2010) define boundary spanning as 'adaptive governance activities of water managers linking their sector, scales, and time frames to previously independent other sectors, scales and time frames.' 'Spanning' in this context refers to space, breadth, and timing to overcome entrenched hurdles to a coordinated approach.
} 
incident-a formal Belgian complaint to the Dutch government-which shows that sovereignty issues always lurk around the corner even when the decision-making process is ostentatively organised as a collaborative learning process (see Box below).

\section{Conclusion}

This special issue considers the role of hegemony in achieving cooperation in two- or multi-level hydro-political settings and games. The existing literature is inconclusive about the potential effects of hydro-hegemony on cooperation (Zawahri, Dinar, and Mitchell 2011). Some argue that hegemony can provide the public good of stability of expectation and hence cooperation (Lowi 1993; Tir and Ackerman 2009; Zawahri and Mitchell 2011), while others suggest that hegemons can use the power of control and consent to achieve coerced cooperation that restrains the gains for the weaker riparians (Zeitoun and Warner 2006; Zeitoun et al. 2011). While unable to conclusively summarise the effects of hydrohegemony, the articles in this special section provide a more dynamic answer to this research question. Moving the literature beyond the traditional state-centric focus and considering the tools of influence available to non-state actors, the articles in this special issue show that actors that have been traditionally conceived of as relatively marginal and weak are in fact capable of contributing to the provision of public goods by 'encouraging' the hydro-hegemonic state to alter its behaviour that is counterproductive to cooperation. The articles also demonstrate that although powerful states can flex their military capabilities at the basin level, domestically they tend to heed to pressures from non-state actors.

The articles in this special issue also illustrate the various tools available to non-state actors to influence the behaviour of hydro-hegemons. Drawing on science and information, these non-state actors can lobby civil servants, organise public protests, draw on litigation, and enlist international allies to pressure hegemonic governments to alter their behaviour. By using their information tools and soft power, NGOs, policy entrepreneurs, and environmentalists are able to move hydro-hegemonic basins that have weak cooperation into a more cooperative direction. While it is important to note that these non-state actors may not be able to completely compel powerful riparian states to alter their interests into a more integrated basin-wide development model that is institutionalised in a basin-wide treaty, they nevertheless do perform positive functions.

It is only through a consideration of domestic politics and the interaction between international and domestic actors that we can advance our understanding of this positive role performed by non-state actors that includes an alternative path towards conflict management.

The special issue introduces certain questions that remain for future research. As noted, we still need a more nuanced understanding of power and hegemony as practiced by basin hegemons and the role of non-state actors, to gain a more conclusive understanding of its impact on cooperation and conflict. Second, the impact of multilateral institutions requires further understanding as to whether they can truly modify riparian states' behaviour and compel basin cooperation. Finally, further research is needed on the consequences of regime type on the power of NGOs to fulfil their objectives. This special issue is unique in that it considers a diversity of regime types, but further empirical research is needed to test the findings regarding any potential variance between democratic and authoritarian regimes. 
Acknowledgments We thank Diana Suhardiman and Oliver Hensengerth for their constructive comments on earlier drafts.

Open Access This article is distributed under the terms of the Creative Commons Attribution License which permits any use, distribution, and reproduction in any medium, provided the original author(s) and the source are credited.

\section{References}

Arendt, H. (1972). Crises of the republic. New York: Harcourt Brace Jovanovich.

Aydin, M. (2003). Securitization of history and geography. Understanding of security in Turkey. Journal of Southeast European and Black Sea Studies, 3(2), 163-184.

Balaban, S. (2006). Dynamics of three level games and implications for policy making. Paper presented at the annual meeting of the Southern Political Science Association. http://www.allacademic. com//meta/p_mla_apa_research_citation/0/6/9/0/5/pages69050/p69050-2.php.

Bernauer, T., \& Kuhn, P. (2010). Is there an environmental version of the Kantian peace? Insights from water pollution in Europe. European Journal of International Relations, 16(1), 77-102.

Bressers, J., \& Lulofs, K. (2010). Governance and complexity in water management. Creating cooperation through boundary spanning. London: Edward Arnold.

Burton, J. W. (1972). World society. Cambridge and New York: Cambridge University Press.

Crow, B., \& Singh, N. (2000). Impediments and innovations in international rivers: The waters of South Asia. World Development, 28(11), 1907-1925.

Currie-Alder, B. (2007). Unpacking participatory NRM: Distinguishing resource capture from democratic governance. In J. Warner (Ed.), Multi-stakeholder platforms for integrated water management. Aldershot: Ashgate.

Daoudy, M. (2009). 'Asymmetric power. Negotiating Water in the Euphrates and Tigris', International Negotiation, 14, 359-389.

de Vries, J. (2008). Breaking the deadlock. Lessons from cross-border spatial projects in Flanders and The Netherland. disP, 172, 48-62.

Dieperink, C. (2011). 'International water negotiations under asymmetry, lessons from the Rhine chlorides dispute settlement (1931-2004)'. International Environmental Agreements: Politics, Law and Economics, 11(2), 139-157.

Edmunds, D., \& Wollenberg, E. (2001). A strategic approach to multistakeholder negotiations. Development and Change, 32(2), 231-253.

Gerlak, A., Lautze, J., \& Giordano, M. (2011). Water resources data and information exchange in transboundary water treaties. International Environmental Agreements, 11, 179-199.

Giordano, M. A., \& Wolf, A. T. (2003). Sharing waters: Post-Rio international water management. Natural Resources Forum, 27, 163-171.

Haufler, V. (1993). Crossing the boundary between public and private. In V. Rittberger (Ed.), Regime theory and international relations. Oxford: Clarendon Press.

Haugaard, M. (2006). Conceptual confrontation. In M. Haugaard \& H. H. Lentner (Eds.), Hegemony and power: Consensus and coercion in contemporary politics. Lanham, MD: Lexington Books.

Huitema, D., \& Meijerink, S. (2010). Realizing water transitions: the role of policy entrepreneurs in water policy change. Ecology and Society, 15(2), 26.

Keck, M. E., \& Sikkink, K. (1998). Activists beyond borders: Advocacy networks in international politics. London, UK and Ithaca, NY: Cornell University Press.

Kistin, E.J. (2006). Qualifying cooperation over transboundary waters. Water for Africa paper. http://splash.bradford.ac.uk/files/myFile_Kistin\%20seminar\%206.pdf.

Knopf, J. W. (1994). Beyond two-level games: Domestic-international interaction in the intermediate-range nuclear forces negotiations. International Organization, 47(4), 599-628.

Le Marquand, D. (1977). International rivers: The politics of cooperation. Vancover: West Water Research Centre, University of British Colombia.

Lowi, M. R. (1993). Water and power: The politics of a scarce resource in the Jordan River basin. Cambridge: Cambridge University Press.

Mearsheimer, J. (2001). The tragedy of great power politics. New York: W. W. Norton \& Company.

Milner, H. V. (1997). Interests, institutions, and information: domestic politics and international relations. Princeton, NJ: Princeton University Press. 
Milner, H., \& Moravcsik, A. (Eds.). (2009). Power, interdependence and non-state actors in world politics: Research frontiers. Princeton: Princeton University Press.

Mirumachi, N. and J.A. Allan (2007). Revisiting transboundary Water. power, conflict, cooperation and the political economy. Proceedings from CAIWA international conference on adaptive and integrated water management: Coping with scarcity, November 12-15, 2007, Basel, Switzerland.

Morin, J. F. (2010). The two-level game of transnational networks: The case of the access to medicines campaign. SSRN Working paper series; Available at SSRN: http://ssrn.com/abstract=1576433.

Morrow, A., \& Al-Omrani, K. Moussa (2010). Upstream states challenge Egypt over Nile waters. 15 June. Online: ipsnews.net/news.asp?idnews=51823. Last consulted 23 March 2012.

Nye, J. (2004). Soft power: The means to success in world politics. New York: Basic Books.

Ohlsson, L. (1995). Hydropolitics. London: Zed Books.

Ohlsson, L., and Turton, A. R. (1999). The turning of a screw: social resource scarcity as a bottle-neck in adaption to water scarcity. SOAS Occasional Paper No. 19. London: School of Oriental and African Studies, University of London.

Prys, M. (2008). Developing a contextually relevant concept of regional hegemony: The case of South Africa, Zimbabwe and 'Quiet Diplomacy,' GIGA working paper No. 77, 2008.

Putnam, R. (1988). Diplomacy and domestic politics: The logic of two-level games. International Organization, 42, 427-460.

Scott, J. (1995). Weapons of the weak: Everyday forms of peasant resistance. Connecticut: Yale University Press.

Shapland, G. (1995). Policy options for downstream states in the Middle East. In J. A. Allan \& C. Mallat (Eds.), Water in the Middle East: Legal, political and commercial implications (pp. 301-323). London: IB Tauris.

Sosland, J. K. (2007). Cooperating rivals: The riparian politics of the Jordan River basin. New York, USA: State University of New York Press.

Starr, J., \& Stoll, D. (1988). The politics of scarcity. Water in the Middle East. Boulder: Westview Press.

Tir, J., \& Ackerman, J. (2009). Politics of formalized river cooperation. Journal of Peace Research, 46(5), 623-640.

Tir, J., \& Stinnett, D. (2011). The institutional design of riparian treaties: The role of river issue. Journal of Conflict Resolution, 55(4), 606-631.

Trondalen, J. M. (2009). Climate change, water security, and possible remedies for the Middle East. The United Nations World Water Assessment Programs. http://unesdoc.unesco.org/images/0018/ 001818/181886e.pdf.

Warner, J. (2004). Mind the GAP-working with Buzan: The Illisu Dam as a security issue. SOAS water issues study group, school of oriental and African Studies/King's College: London (Occasional Paper $67)$.

Warner, J. (2008). Contested hydro-hegemony/hydraulic control and security in Turkey. Water Alternatives, $1(2), 271-288$.

Warner, J. (2010). Hydrohegemonic politics: A crossroads on the Euphrates-Tigris? In K. Wegerich \& J. Warner (Eds.), The politics of water. London: Routledge.

Warner, J., \& van Buuren, A. (2009). Multi-stakeholder learning and fighting on the river Scheldt. International Negotiation, 14(2), 419-440.

Watson, A. (2007). Hegemony and history. London: Routledge.

Wegerich, K., \& Warner, J. (Eds.). (2010). The politics of water. London: Routledge.

Weiss, J.C. (2010). Autocratic Audiences, international bargaining, and nationalist protest in China. http://www9.georgetown.edu/faculty/jrv24/Weiss_08.pdf.

Werners, S. E., Warner, J., \& Roth, D. (2010). Opponents and supporters of water policy change in the Netherlands and Hungary. Water Alternatives, 3(1), 26-47.

Wesselink, A., Warner, J., \& M. Kok (2011). You gain some funding, you lose some freedom: The ironies of better flood protection in Limburg (The Netherlands). Paper presented during the interpretative studies association annual conference 20011 in Cardiff, July 2011.

Williams, P. (2002). The competent boundary spanner. Public Administration, 80(1), 103-124.

Williams, P. (2003). The security politics of enclosing transboundary river water resources. Paper presented at the International Conference on Resource Politics and Security in a Global Age, University of Sheffield (UK), June 26-28, 2003.

Wolf, A. (1995). Hydropolitics along the Jordan river. Tokyo: United Nations University Press.

Wolf, A. (1998). Conflict and cooperation along international waterways. Water Policy, 1(2), 251-265.

Zawahri, N. (2006). Stabilising Iraq's water supply: What the Euphrates and Tigris can learn from the Indus. Third World Quarterly, 27(6), 1041-1058. 
Zawahri, N. (2008). International rivers and national security: The Euphrates, Ganges-Brahmaputra, Indus, Tigris, and Yarmouk Rivers. Natural Resources Forum, 32, 280-289.

Zawahri, N. (2010). Governing the Jordan river system: History, challenges, and outlook (pp. 127-147). Water Resources: Journal of Transboundary.

Zawahri, A., Dinar, S., \& Mitchell, S. (2011). Facilitating treaty formation to govern international rivers. International Studies Quarterly, 55(3), 803-807.

Zawahri, N., \& Mitchell, S. (2011). Fragmented governance of international rivers: Negotiating Bilateral versus Multilateral Treaties. International Studies Quarterly, 55(3), 835-858.

Zeitoun, M., Mirumachi, N., \& Warner, J. (2011). Transboundary water interaction II: Soft power underlying conflict and cooperation. International Environmental Agreements, 11, 159-178.

Zeitoun, M., \& Warner, J. (2006). Hydro-hegemony: A framework for analysis of transboundary water conflicts. Water Policy, 8, 435-460. 